\title{
HIV/AIDS Infection Knowledge in General Population of Northern Mexico

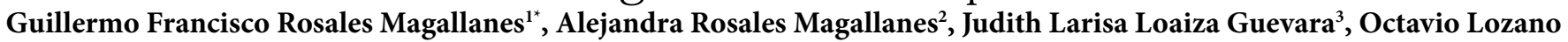 Salazar ${ }^{3}$, Cindy Verónica Ibarra Santillanes ${ }^{4}$ and Eduardo Daniel Becerra Cárdenas ${ }^{4}$
}

${ }^{1}$ Infectious diseases paediatrician, Hospital ISSSTECALI Mexicali, Baja California, Mexico

${ }^{2}$ Biostatistics, Autonomous University of Baja California, Segunda, 21100 Mexicali, B.C., Mexico

${ }^{3}$ Faculty of Medicine, Autonomous University of Baja California, Segunda, 21100 Mexicali, B.C., Mexico

${ }^{4}$ Medical school, Xochicalco Calmecac University. Mexicali Campus, Mexico

\section{Abstract}

Publication History:

Aim: In 2016 Baja California went up to the sixth place in incidence of cases from HIV/AIDS. People Received: July 28, 2018 are getting used to the disease and stopped paying attention to it. To understand this tendency we must Accepted: August 29, 2018 determine grade knowledge of the population.

Published: August 31, 2018

Material and methods: Descriptive, transversal and correlative study. 400 people between 17-74 years old were surveyed with an instrument consisting in a polytomous test of 27 items about HIV/AIDS, covering: general knowledge, mechanism of transmission and its prevention. Groups were divided by sex and age: 17-30, 31-45, 46-60, $>60$ years old. Results were considered sufficient when more than $80 \%$ of answers were correct, regular for $60-79 \%$, and deficient if $<59 \%$. Also; age, sex, scholarship and grade of knowledge were determinated. Odds ratios were made to findcorrelation.

\section{Keywords:}

Anemia, Children, Crohn's Disease, Health Related Quality of Life, Inflammatory Bowel Disease,

Results: Those surveyed were 228 women and 172 men (43\%); $58.5 \%$ between 17 and 30 years old, Ulcerative colitis $22.5 \%$ from 31 to $45 ; 15.5 \%$ from 46 to 60 and $3.5 \%$ were $>60$ years old. The average age was 31 years. Scholarship: $41.5 \%$ (166) were currently bachelor students. $20.75 \%$ obtained a degree. $16.7 \%$ graduated from high school. The average qualification was $66.9 \%$. Prevention knowledge was very low (26\% of answered correctly). $30 \%$ showed deficient knowledge. Once correlation tests were made, no statistical relation was found between sex, age and level of knowledge $(\mathrm{p}=>0.005)$.

Conclusions and Recommendations: Most of general population lack of knowledge, there is too much misinformation about prevention. We recommend more sex education programs at all levels.

\section{Introduction}

In recent years Baja California has been ranked on the top ten most affected areas in Mexico. In 2015, it placed 8th and by 2016 it had gone up to the 6th. Since its recognition for the first time in 1981, no other condition has captured as much attention in scientific research as the human immunodeficiency virus, being identified as one of the most lethal infectious diseases of major public health concern, due to it not discriminating class, age, sex, religious beliefs or race. Its incidence has increased dramatically in recent decades despite all efforts by organizations to keep it contained, and in the end no favorable results have been obtained. People seem to be getting used to the disease and have stopped paying attention to it, while the probability of a close one being infected increases every day. In order to understand this trend we must know the grade knowledge in the general population of the capital city, to search for strategies to try to contain the problem with this information.

\section{Material and Methods}

Descriptive, transversal and correlative study. Performed in the city of Mexicali, Baja California, Mexico. After informed consent for research, 400 surveys were applied to people between 17 and 74 years old according to the criteria of selection of total population currently living in the city of Mexicali B.C. (2017) to have a CI of 95\%. General data including sex, age, highest level of school completed and occupation were obtained. The instrument performed is a previously validated survey for measuring the level of knowledge in general population. Authors were notified and once the permission was obtained to employ their instrument, this polytomous survey adapted to 27 items about the infection by HIV/AIDS was applied, three fields were evaluated: general knowledge, mechanism of disease and prevention. Groups were divided by sex (male/female) and age: 17-30, 31-45, 46-60, >60 years old. 27 statements were listed and participants were asked to answer each question as true, false or if they didn't know the answer. Responses were captured by Microsoft excel version 14.0.7177.5000. The final information was analyzed, and the result of each participant was evaluated as; sufficient when $80 \%$ or more were correct; regular knowledge if they achieve from 60 to $79 \%$ correct answers, and deficient if they achieve less than $59 \%$ correct answers. Odds ratios were determined to evaluate if there is a relationship between age/grade knowledge or between sex/grade knowledge.

\section{Results}

According to the Planning Committee for State Development (from his acronym in Spanish COPLADE) Mexicali, Baja California had a total of 1,039,257 citizens during 2016, in which people between the group age of $17-75$ year old corresponded to $70.5 \%$ of the total population $(733,053$ people), in which $49.79 \%(365,015)$ were female and $50.21 \%$ were male. A representative pool of 400 surveys were calculated to have a confidence interval (CI) of $95 \%$.

"Corresponding Author: Dr. Guillermo Francisco Rosales Magallanes, Infectious diseases paediatrician, Hospital ISSSTECALI Mexicali, Brindisi 1401 Gran Venecia, Mexicali, Baja California, Mexico, Tel: 6865522278; E-mail: dr_gmagal76@hotmail.com

Citation: Magallanes GFR, Magallanes AR, Guevara JLL, Salazar OL, Santillanes CVI, et al. (2018) HIVIAIDS Infection Knowledge in General Population of Northern Mexico. Int J Pediatr Neonat Care 4: 143. doi: https://doi. org/10.15344/2455-2364/2018/143

Copyright: (c) 2018 Magallanes et al. This is an open-access article distributed under the terms of the Creative Commons Attribution License, which permits unrestricted use, distribution, and reproduction in any medium, provided the original author and source are credited. 
Citation: Magallanes GFR, Magallanes AR, Guevara JLL, Salazar OL, Santillanes CVI, et al. (2018) HIV/AIDS Infection Knowledge in General Population of Northern Mexico. Int J Pediatr Neonat Care 4: 143. doi: https://doi.org/10.15344/2455-2364/2018/143

Page 2 of 5

elementary school; $9.5 \%$ (38) graduated from middle school; $16.75 \%$ (67) graduated from high school; 20.75\% (83) obtained a bachelor's degree; $5 \%$ got a master's degree $(20) ; 1 \%(4)$ had a doctorate and $3.75 \%(15)$ had a technical career (Figure 1).

The average qualification of the participants in the survey was 66.9 (global level of regular knowledge), with an average of 18 correct answers (a minimum of 5 and a maximum of 27 correct answers). The results for each one of the items enlisted in the survey are summarized in the table 1 . Once the results were analyzed for each item, the fields that showed more deficient results were determined. About general information of HIV/AIDS a $49 \%$ of the surveyed answer correctly (19), followed by mechanisms of VIH/AIDS with a 39\% (15), nerveless the results showing an important deficiency in the area of prevention with an average of $26 \%$ of the surveyed answered correctly (104). Analyzing the result by group of age; $48 \%$ of the surveyed (114) within the age group of $17-30$ years $(n=234)$ have regular knowledge level about VIH/AIDS, 32\% (76) have a deficient global knowledge and only $18 \%$ (44) have enough knowledge. In the 31 to 45 years group $(n=90)$ the $53 \%$ of the surveyed (48) had a regular level

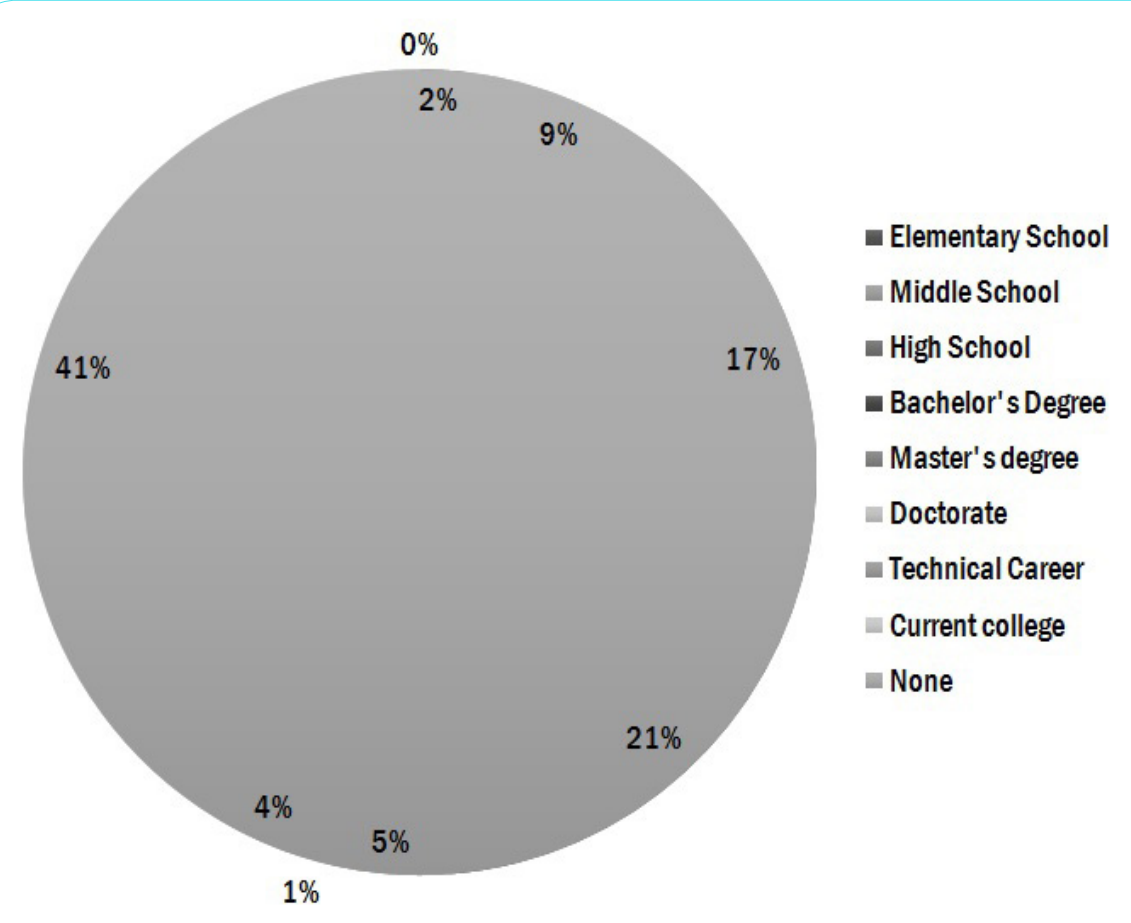

Figure 1: Academic level of participants.

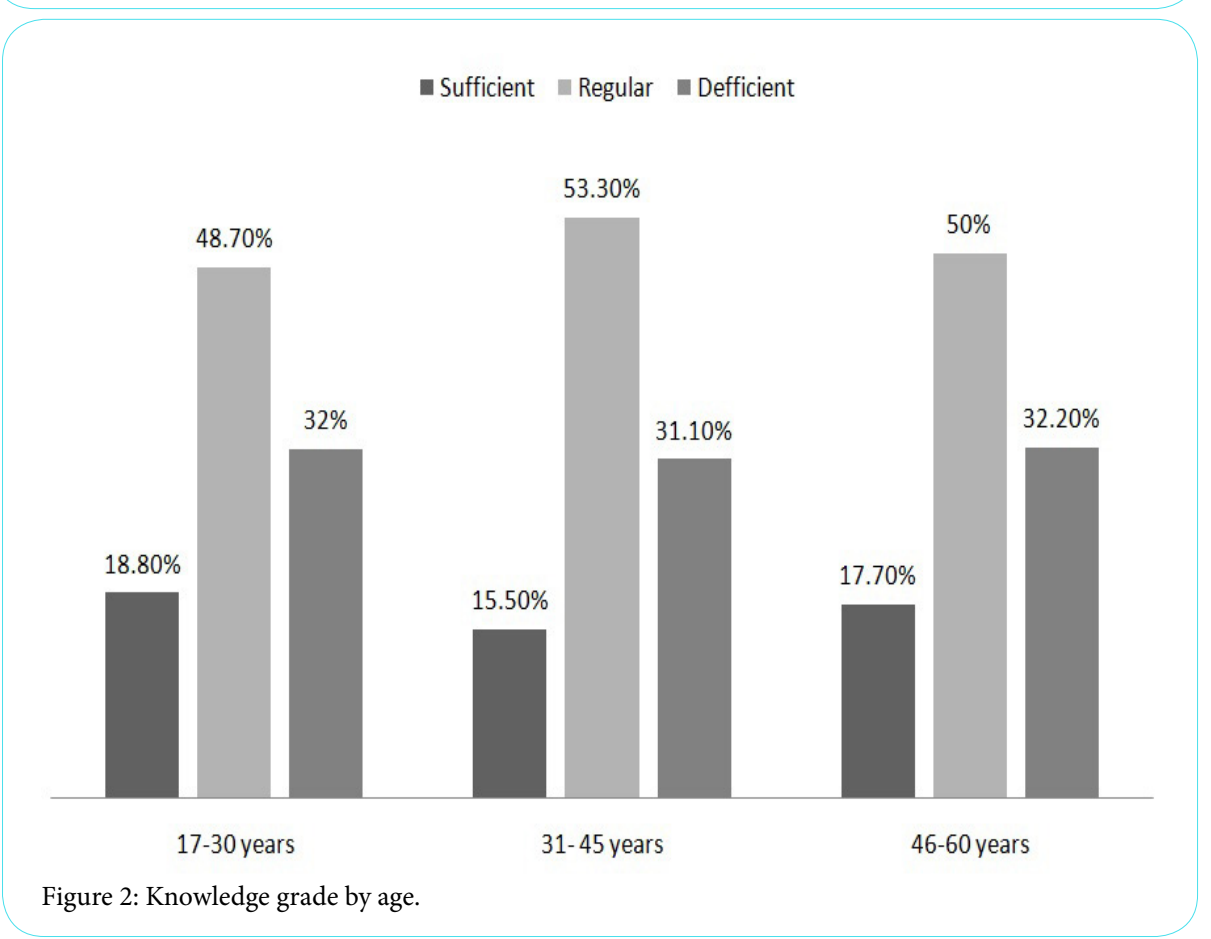


Citation: Magallanes GFR, Magallanes AR, Guevara JLL, Salazar OL, Santillanes CVI, et al. (2018) HIV/AIDS Infection Knowledge in General Population of Northern Mexico. Int J Pediatr Neonat Care 4: 143. doi: https://doi.org/10.15344/2455-2364/2018/143

Page 3 of 5

of knowledge, $31 \%$ (28) have enough knowledge and only a $15 \%$ of this (14) with enough awareness about the disease. In the group of 46 to 60 years $(n=62)$ The highest proportion showed that $50 \%$ of the participants obtained regular results (31), 32\% of this (20) have deficient information and $18 \%$ (11) have an enough level of knowledge. Within the group of older than 60 years old $(n=14)$ a $35 \%$ (5 of them) have enough level of knowledge, although this is the group who have less participants in proportion with the rest of groups, therefore their results aren't statistically significant and it can't be comparable with the rest of the groups to determine whether this category have the best level of knowledge. Once correlation tests were made, no statistical relation was found between sex, age and level of knowledge $(\mathrm{p}=>0.005)$ (Figure 2, Table 1 and Table 3$)$.

\section{Discussion}

While the Worlds Health Organizations' 90-90-90 strategy made an enormous effort to lower the global incidence of HIV/AIDS by the year 2020, it has come upon another obstacle in order for it to come to fruition: an uninformed populace [1]. It would seem that despite the many studies that support this strategy as well as much clinical experience shared on the internet we still have people with a lack of knowledge in regards to this issue. Some issues have already been made known regarding the 90-90-90 strategy such as the increased need of supply and our inability to provide it, however, before we can even begin to question whether or not we can supply the populace with enough antiretroviral medicine, we must accomplish the first step in this strategy: diagnose $90 \%$ of the people with HIV [2]. In order to do

\begin{tabular}{|l|l|l|l|l|l|l|}
\hline Age / Gender & $17-30$ & $31-45$ & $46-60$ & $>60$ & Total & $\%$ \\
\hline $\mathrm{M}$ & 92 & 45 & 28 & 7 & 172 & $43 \%$ \\
\hline $\mathrm{F}$ & 142 & 45 & 34 & 7 & 228 & $57 \%$ \\
\hline Total & 234 & 90 & 62 & 14 & 400 & $100 \%$ \\
\hline
\end{tabular}

Table 2: Gender and age of participants.

\begin{tabular}{|l|l|l|l|}
\hline & Transmission & Prevention & General knowledge \\
\hline Correct answers & 197.875 & 157.7857 & 105.6 \\
\hline$\%$ & $39.446 \%$ & $26.4 \%$ & $49.469 \%$ \\
\hline
\end{tabular}

Table 3: Correct answers by field of knowledge.

\begin{tabular}{|c|c|c|c|}
\hline & Question & Correct Answers & Rate \\
\hline 1. & AIDS is caused by a virus called HIV & 378 & $94.5 \%$ \\
\hline 2. & Baja California State is one of the most affected areas of AIDS & 113 & $28.2 \%$ \\
\hline 3. & The main route of transmission of HIV in Baja California is through intercourse & 334 & $83.5 \%$ \\
\hline 4. & Pets and domestic animals can transmit the AIDS virus & 21 & $5.2 \%$ \\
\hline 5. & A pregnant HIV-positive woman can transmit HIV to her baby & 273 & $68.2 \%$ \\
\hline 6. & HIV-positive people can transmit the AIDS virus even if they are not sick & 117 & $29.2 \%$ \\
\hline 7. & HIV is transmitted through vaginal and seminal secretions and blood & 364 & $91 \%$ \\
\hline 8. & HIV/AIDS is transmitted through the air & 1 & $0.2 \%$ \\
\hline 9. & It is dangerous to share food or water with people living with HIV or AIDS & 46 & $11.5 \%$ \\
\hline 10. & $\begin{array}{l}\text { Washing your clothes with those of an HIV-positive or AIDS-infected person implies risk of contracting the } \\
\text { disease }\end{array}$ & 23 & $5.7 \%$ \\
\hline 11. & Mosquitoes can transmit HIV & 108 & $27 \%$ \\
\hline 12. & There is a risk of getting HIV from sharing contaminated syringes & 380 & $95 \%$ \\
\hline 13. & HIV affects the human immune system & 371 & $92.7 \%$ \\
\hline 14. & HIV affects all the cells of the human organism & 251 & $62.7 \%$ \\
\hline 15. & Window period refers to the time it takes the human body to produce antibodies after HIV transmission & 118 & $29.5 \%$ \\
\hline 16. & The vaginal ring or the IUD are effective methods to avoid AIDS & 29 & $7.2 \%$ \\
\hline 17. & Contraceptive pills are effective in preventing the transmission of HIV during sexual intercourse & 19 & $4.7 \%$ \\
\hline 18. & Condoms are an effective way to prevent HIV transmission & 330 & $82.5 \%$ \\
\hline 19. & The female condom is not as effective as the male condom to prevent transmission of the AIDS virus & 110 & $27.5 \%$ \\
\hline 20. & Giving a french kiss to an HIV-positive person is a risk for HIV transmission & 80 & $20 \%$ \\
\hline 21. & Hugging and kissing an HIV-positive person on the cheek implies risk to HIV transmission & 2 & $0.5 \%$ \\
\hline 22. & Intercourse by doing $<<$ pull-out method $>>$ is a safe way to have sex without risk of HIV infection & 22 & $5.5 \%$ \\
\hline 23. & HIV testing is usually performed through a blood test & 378 & $94.5 \%$ \\
\hline 24. & It is possible to know if there is HIV infection the next day after a risk practice & 41 & $10.2 \%$ \\
\hline 25. & Current medical treatments can reduce the amount of HIV in the body & 146 & $36.5 \%$ \\
\hline 26. & There is currently a vaccine against HIV infection & 40 & $10 \%$ \\
\hline 27. & $\begin{array}{l}\text { Infections and diseases that appear due to the weakening of the immune system by action of HIV, are called } \\
\text { "opportunistic infections" }\end{array}$ & 165 & $41.2 \%$ \\
\hline
\end{tabular}

Table 1: "Summary of findings on HIV/AIDS knowledge". 
Citation: Magallanes GFR, Magallanes AR, Guevara JLL, Salazar OL, Santillanes CVI, et al. (2018) HIV/AIDS Infection Knowledge in General Population of Northern Mexico. Int J Pediatr Neonat Care 4: 143. doi: https://doi.org/10.15344/2455-2364/2018/143

Page 4 of 5

this we need an informed audience, not it is not simply enough to increase screening, however as we are moving forward with this strategy we seem to be facing a rather unsympathetic populace. Whether it is due to lack of interest, fear of the subject, lack of knowledge, having grown accustomed to the issue, or simply lack of time, we have failed to grow consciousness of the disease. To this day those whom are infected accept responsibility of their illness rather quickly, perhaps due to the moral weight that it implies and perceive themselves as guilty of the choices they have taken. The 20th century pandemic has followed us into the next millennium, despite great efforts from all health organizations. HIV and AIDS have increased their frequency, impacting the vulnerable population, particularly from Baja California, part of the top ten most affected areas in our country, which has continuingly deteriorated Mexico's health services that were already at risk of being entirely consumed [3-11]. Young and economically active population are exposed to misinformation, having television, radio or the news as main source for information regarding HIV and AIDS infection. There's the question in people's mind regarding what needs to be done for a change, to take place and for social responsibility to be a norm when it comes to the sexual liberation that has been increasing for the past three decades, causing children to learn about sexuality from their equally uninformed friends that easily obtain the information from the internet. With information more accessible than ever, anyone can get a hold of sexual information and use it to educate themselves; thus, the youth is being educated by the media, however this in itself is a problem. A study done in southern Ethiopia sought to investigate the level of knowledge the out-of-school youth had about STDs, particularly HIV/AIDS, and the patterns of their sexual activity, what they found was that this population engaged in high risk sexual activities and had very little knowledge about HIV. They reported that only $13.5 \%$ of their sample of 375 people had used a condom at the time of their first sexual relationship and up to a third of the population reported having relationships with more than one sexual partner in the previous six months [12]. Our results are not only overwhelming but they also allow us to see the tip of the iceberg that every day is growing heavier due to the complications it leaves: absence of parents, children, young people, much pain and mortality. Based on the results, HIV and AIDS intervention programs are necessary in areas where they have never been carried out before, but there's a necessity for them to reach new levels to stop it from spreading even more. A study done in African Americans living in the southern region of the United States demonstrated that HIV knowledge decreased with age and that the more educated individuals where more informed about HIV than people who had only finished high school [13]. The focus of our efforts must be individuals between 17 and 45 years old, since they're at significant risk by being sexually active and lacking awareness. The article by Udell and Donenberg illustrates that youth is lacking in knowledge about the disease, in particular about "HIV-safe" behavior, which is similar to what our results demonstrated since the most deficient field was that of prevention [14]. Regarding the areas of knowledge, our results were similar to those conducted in similar studies, in order to create awareness emphasis should be placed on strategies to guide and inform the population about preventive measures towards HIV / AIDS, being the most deficient field in our study group; followed by the mechanisms of transmission, where many correct answers were obtained, but guidance is still needed to create awareness of the realities and myths that are popularly known and, at the same time, the misconceptions and prejudices that continue to present themselves in today's society [15-21]. Another study sought to identify the source of information from college students from
China and the US demonstrated that the two most popular sources of information were the internet or from traditional media, this is rather alarming as the internet was the most popular choice and it often has unfiltered and erroneous information. Let's face it, this is about not only offering information, we must get to the heart of the problem, impact a society with a more open mind compared to their predecessors, the numbers are there, the mortality and the myriad of damage remains, only, it would seem nobody cares about it, only those involved conscious about it and only after the damage is done. The question is in the air, the strategies are there, the tools remain, yet not much has been done. What to do? How to do it? Where to begin? Education is the answer; the objective is to leave an impression. This is the challenge, the responsibility is ours. We should not only worry about forming ourselves as resolvers of a latent problem, we should work in the most important part without infringing in the human rights of these individuals. We can manage it, and then and only then, can we achieve these goals, even those to 2030 .

\section{Conclusions and Recommendations}

Results showed that a large part of the capital's general population is not properly educated regarding HIV and AIDS, the misconceptions on the subject were shared by people of all ages and genders; although most of them were young people, it's clear that there's a lot of misinformation regarding prevention, the most important aspect.

The general public's knowledge leans towards the generalities of HIV / AIDS infection, but we still have to cover a larger percentage of the population for this information to be available for everyone. It is recommended that more programs of outpatient sexual education becomes implemented in schools and hospital institutions for preventive measures in adolescence, before starting the active sex life. It is essential to inform parents that they must share the information with their children; such an important topic is not only responsibility of health services, the initial education begins at home.

\section{Competing Interests}

The authors declare that no competing interests is present.

\section{References}

1. 90-90-90 An ambitious treatment target to help end the AIDS epidemic (2014) UNAIDS.

2. Jamieson D, Kellerman SE (2016) The 909090 strategy to end the HIV Pandemic by 2030: Can the supply chain handle it? J Int AIDS Soc 19: 20917

3. SS/CENSIDA (2013) Boletín No. 23 SALVAR: Datos al 31 de diciembre de 2013. México: Centro Nacional para la Prevención y el Control del VIH y el sida.

4. SS/CENSIDA (2016) Vigilancia Epidemiológica de casos de VIH/SIDA en México Registro Nacional de Casos de SIDA Actualización al 15 de noviembre de 2016 .

5. SS/CENSIDA (2014) Informe Nacional de Avances en la Respuesta al $\mathrm{VIH}$ y el sida. México.

6. SS/CENSIDA (2015) La epidemia del VIH y el SIDA en México.

7. ONUSIDA/JC2502/1//S (2013) Informe mundial: ONUSIDA, informe sobre la epidemia mundial de sida 2013

8. Strathdee S, Magis-Rodriguez C (2008) Mexico's Evolving HIV Epidemic. JAMA 300: 571-573.

9. CENSIDA (2013) Vigilancia Epidemiológica de casos de VIH/SIDA en México Registro Nacional de Casos de SIDA Actualización al cierre de 2013 
Citation: Magallanes GFR, Magallanes AR, Guevara JLL, Salazar OL, Santillanes CVI, et al. (2018) HIV/AIDS Infection Knowledge in General Population of Northern Mexico. Int J Pediatr Neonat Care 4: 143. doi: https://doi.org/10.15344/2455-2364/2018/143

Page 4 of 5

10. Iñiguez-Stevens E, Brouwer KC, Hogg RS, Patterson TL, Lozada R, et al. (2009) Estimaciones de Prevalencia del VIH por Género y Grupo de Riesgo en Tijuana, México: 2006. Gac Med Mex 145: 189-195.

11. Zapata-Garibay R, González-Fagoaga J, Rangel-Gómez M (2014) Mortalidad por VIH/SIDA en la frontera norte de México: niveles y tendencias recientes. Pap poblac 20: 39-71.

12. Taffa N (1997) Sexual activity of out-of-school youth, and their knowledge and attitude about STDs and HIVIAIDS in Southern Ethiopia.

13. Klein H, Sterk CE, KW Elifson (2016) Knowledge about HIV in a Community Sample of Urban African Americans in the South. J AIDS Clin Res, 7: 622.

14. Udell W, Donenberg G (2015) Remembering the Basics: African American Youth and HIV Knowledge-Brief Report. J Natl Med Assoc 107: 20-24.

15. Jiménez Ruíz A, Jiménez García F, TenahuaQuitl I, Grajales Alonso I (2011). Nivel de conocimientos de los adolescentes sobre el Virus de Inmunodeficiencia Humana/ Síndrome de Inmunodeficiencia Adquirida. Scielo.

16. Díaz Montes C, Cantillo Uribe L, García Vergara K, Martínez Marenco L, Vega Recuero J, et al. (2014) Conocimientos sobre vih/sida en adolescentes de una universidad en cartagena-colombia, 2011.

17. Pernaz-Linsuy G, Cárcamo-Cavagnaro C (2015) Conocimientos, actitudes y prácticas de la mujer peruana sobre la infección por VIH/SIDA. Rpmesp ins gob pe.

18. Pachas C, Cilene S, Gallo Q, Lisset K (2012) Nivel de conocimientos, factores de riesgo y medidas de prevención sobre $\mathrm{VIH} /$ sida en estudiantes adolescentes de dos instituciones educativas en la ciudad de lima, 2012. Repositorio uwiener edu pe.

19. Sarduy Lugo M, Sarduy Lugo A, Cabañín LEC (2015) Nivel de conocimientos sobre VIH/sida en estudiantes de secundaria básica. Revista Cubana De Enfermería.

20. García-Mora A, Mendoza-Brizio M, González-Gutiérrez A, HernándezGonzález M, Ginnette Ortega-Escamilla P, et al. (2016) Conocimientos y prácticas de riesgo ante el VIH/SIDA en adolescentes de la Facultad de Planeación Urbana y Regional de la Universidad Autónoma del Estado de México. Elsevier

21. Caballero Hoyos R, Villaseñor A, Hidalgo MA (1997) Fuentes de información y su relación con el grado de conocimientos sobre el SIDA en adolescentes de México. Rev Saúde Pública 31: 351-359. 